\title{
E-BRIEF
}

October 7, 2015

\author{
MONETARY POLICY
}

\section{One Percent? For Real? Insights from Modern Growth Theory about Future Investment Returns}

\author{
by
}

Steve Ambler and Craig Alexander

- The outlook for interest rates in the longer term is a vital concern for retirement savers, pension fund managers and policymakers alike. Will rates return to "normal" levels after sitting at record lows for so long? Will the new normal level be lower than in the past?

- Modern economic growth theory provides insights into the future course of interest rates. Specifically, it can help inform expectations for the equilibrium level of "risk-free" real interest rates, like those on inflation-adjusted Treasury bills for example, over the long run. Since the risk-free rate is the foundation upon which all risk premiums - for inflation, the term of the investment, and the possibility of default - are applied to estimate future returns by asset class, economic growth theory provides a key perspective to long-term investors.

- A wide range of models predict that the level of the real risk-free interest rate should be greater than the real rate of growth of per capita income over the long run. In the Canadian context, the impact of an aging population is expected to lower the rate of growth in real income per capita to an average annual pace of between 0.75 and 1.35 percent over the next couple of decades. Taking the lower end of that range as a floor, the implication is that real returns on risk-free investments can only be counted on to be close to 1 percent.

A central issue in retirement saving is the expected return on portfolios over the long haul. For defined-benefit pension plans, if the realized return is inadequate to meet future liabilities, there will be difficulty in making the targeted payments to plan participants, or in the worst case,

The authors wish to thank several anonymous reviewers and Alexandre Laurin, Director of Research at the C.D. Howe Institute, for comments on earlier drafts of this publication. The authors retain responsibility for any errors and the views expressed here. 
there could even be a solvency problem. For defined-contribution pension plans and other money-purchase arrangements, the risk lies with the participant, as lower-than-expected returns could lead to inadequate income replacement.

One approach for building projections for asset class returns is to start with an assessment of the level of the real "risk-free" interest rate, and then apply premiums for various risks, including inflation, term, default and liquidity. It is important to stress that the level of real risk-free rates will vary by country. In this paper, the focus is on the real risk-free interest rate in Canada for judging potential returns on Canadian financial assets. The riskfree interest rate is the minimum return that investors will accept on an investment with negligible risk associated with it. From a market perspective, the closest approximation to the real risk-free rate is the return on threemonth T-bills, after removing inflation. Since three-month T-bills trade at a very small spread to the benchmark overnight rate that the Bank of Canada targets for monetary policy purposes, the real risk-free interest rate is also effectively the same as the estimate of the 'neutral' level of the policy rate - the rate that would be consistent with stable 2 percent inflation over the long term.

Modern economic growth theory provides a way of anchoring expectations for the long-run level of real riskfree interest rates on the basis of projected long-run rates of real per capita economic growth (i.e., the growth rate in the volume of economic output per person). This approach is, in principle, superior to extrapolating from past performance. Specifically, growth theory implies that the risk-free real rate of return should be greater than the average rate of growth of per capita output over a multi-decade period. In other words, it establishes a long-term floor to riskless investment returns.

In the Canadian context, the impact of an aging population is expected to lower the rate of growth in real income per capita to an average annual pace of between 0.75 and 1.35 percent over the next couple of decades. Taking the lower end of that range as a floor, the implication is that real risk-free investments can only be counted on to return close to 1 percent.

Overall, the difference between the projected portfolio returns and the risk-free rate provides insight into how much risk a pension fund is taking to achieve its goals. For example, if one assumes that the Bank of Canada maintains its 2 percent inflation target, then the nominal level of risk-free rates should be close to 3 percent. This means, for example, a portfolio manager counting on a 7 percent annual return to meet future obligations will not be successful by investing solely in risk-free assets. Hence, an assessment of the risk-free rate can help pension managers, trustees and policymakers understand one dimension of the risk profile of a portfolio.

\section{A Basic Formula from Growth Theory}

Neoclassical growth theory starts from the premise that households maximize their "utility," or the satisfaction from consuming goods or services, and that the economy in equilibrium fluctuates around a "balanced growth path." ${ }^{11}$ The riskless rate of return will depend on the following factors.

(i) The riskless rate of return is positively related to households' impatience. Impatient households will forego current consumption only if they expect a reward of more consumption later. For example, they

1 The classic reference for the neoclassical growth model is Ramsey (1928). Romer's advanced macroeconomics text (2012) has a detailed presentation of the model. The technical, online Appendix to this E-Brief demonstrates the basic relationship discussed in this section. 
might put off buying a Taurus to buy to a BMW later. The more impatient they are, the more they must be compensated to postpone consumption.

(ii) The riskless rate of return is positively correlated with per capita growth. If households expect income per capita to increase, they will wish to borrow to enjoy higher consumption immediately. Their efforts to do so eventually push the cost of borrowing up as lenders respond to demand, until the riskless real interest rate is high enough to discourage current consumption and bring markets into equilibrium. The size of this effect depends on households' willingness to substitute future consumption for present consumption. ${ }^{2}$ Empirical estimates of this degree of willingness to save for the Canadian and other economies suggest that the real interest rate must be higher than the rate of economic growth. ${ }^{3}$

(iii) The riskless rate of return is positively correlated with population growth. The intuition here is that the rate at which households discount the consumption satisfaction of unborn future generations relative to their own will rise if people expect the future population to be larger. The less they care about future generations, the higher the reward they will demand for foregoing consumption. This leads the riskless real rate of interest to increase with the rate of population growth.

An algebraic derivation of the equilibrium level of the real risk-free interest rate on the basis of impatience, economic growth, and population growth is presented in the online Appendix to this E-Brief. The central finding is that the risk-free interest rate over the long run should be higher that the growth rate in per capita output. This must hold along a "balanced growth path," which means that it should be the case on average. To be clear, the level of risk-free rates in the market, as captured by real three-month T-bill rates, will rise and fall over economic cycles, and will vary relative to per capita income growth for potentially long periods of time. But riskfree rate levels are inherently constrained by a fundamental relationship relative to real per capita output growth over the long run.

A natural question is whether the economic theory holds up in the real world? A large body of empirical evidence suggests that it does. The following two studies are examples. ${ }^{4}$

(i) Attfield and Temple (2010) present econometric evidence in favor of the balanced growth hypothesis for both the United States and the United Kingdom, which would imply that the risk-free rate of return exceeds per capita growth.

(ii) Abel et al. (1989) come at the problem from another angle. If the riskless rate of return is less than the growth rate of output, the economy is described as "dynamically inefficient": it would be technically possible to make all individuals better off (now and in the future) by reducing the rate of investment in physical capital goods. ${ }^{5}$ By shifting some of current output to consumption, the capital stock is actually

2 This is known by the technical term "intertemporal elasticity of substitution."

3 Havranek et al. (2013) survey the empirical literature and conduct a meta-analysis of results from 169 published studies covering 104 countries. The results vary across countries but in general support this conclusion.

4 Piketty (2014) also presents (somewhat controversial) international evidence covering over a millennium. He shows that pre-tax rates of return (which may be the ones relevant for pension managers) have mostly been higher than rates of economic growth, although after subtracting taxes and capital losses the rate of return was lower than economic growth for a part of the last century that includes the two world wars.

5 See also Mankiw (2015) for a summary of the argument. 
made more productive so that consumption can increase in the present and the future. They show that there is strong evidence that the American economy is dynamically efficient. ${ }^{6}$

Another natural question is whether the relationship can be observed in Canadian data. Again, it must be stressed that the relevant timeframe from an economic perspective is over the long run, which can mean decades. A 30-year or greater horizon is not an unreasonable basis to look at in thinking about retirement saving. Abel et al. (1989) show that dynamic efficiency holds for the United Kingdom, Germany, France, Italy, Japan and Canada for the period from 1960 to 1982.

The relationship holds in the Canadian data from 1960 to 2010 with the average real three-month T-bill yield at auction averaging 0.2 percentage points above the growth rate in Canada's real income per capita. Over the 30-year period from 1980 to 2010, the real risk-free rate was double the pace of real per capita growth. There was considerable volatility over this timeframe, with long periods where the two measures differed significantly. Indeed, the real risk-free rate was lower than the growth rate of real income per capita in the 1960s and 1970s, but was higher in the 1980s and 1990s.

Moreover, it should be noted that the trend decline in the real risk-free rate over the 1960 to 2010 period corresponded with a trend decline in real GDP per capita growth, which fell from an average 2.9 percent between 1960 and 1979 to a subdued pace of 1.4 percent between 1980 and 2010, which is exactly what economic theory predicts should have happened (Figure 1).

\section{Enter the Secular Stagnation Debate}

Recent experience, however, shows just how real risk-free rates and real per capita growth can deviate. From 2008 to 2014, the average yield at auction of three-month T-Bills had a return below the rate of inflation, with a real yield of -0.66 percent. While real per capita output growth slowed during that period, the average pace has been positive. The sustained economic weakness and the inability of low interest rates to boost economic growth has led to an economic debate about whether the environment is the temporary result of the legacies from the last financial crisis or whether something has fundamentally changed. The latter view has been coined "secular stagnation."7

The remarkable and sustained decline in yields on US 10-year Treasuries is often used to support the stagnation argument. While yields tend to decline during periods of economic weakness, this time yields have remained below what would be typical during the economic recovery. If the secular stagnation argument is true, economic growth could be lower than generally predicted, providing an even lower floor under the risk-free rate in the long run.

However, history is filled with examples of claims that 'the world is different this time,' only to have those claims disappointed with time. For example, proponents of the "Great Moderation" argued that during the early 2000s macroeconomic volatility had been reduced by well-anchored monetary policy and other factors. For

6 Barbie, Hagedorn and Kaul (2004) relax some of the restrictive assumptions that Abel et al. use but reach the same conclusions concerning the dynamic efficiency of the US economy.

7 See also Gordon (2012), Baldwin and Teulings (2014), Jones and Fernald (2014), and Summers (2014) for arguments on both sides of the issue. 


\section{Figure 1: Real GDP per Capita in Canada (1960-2010)}

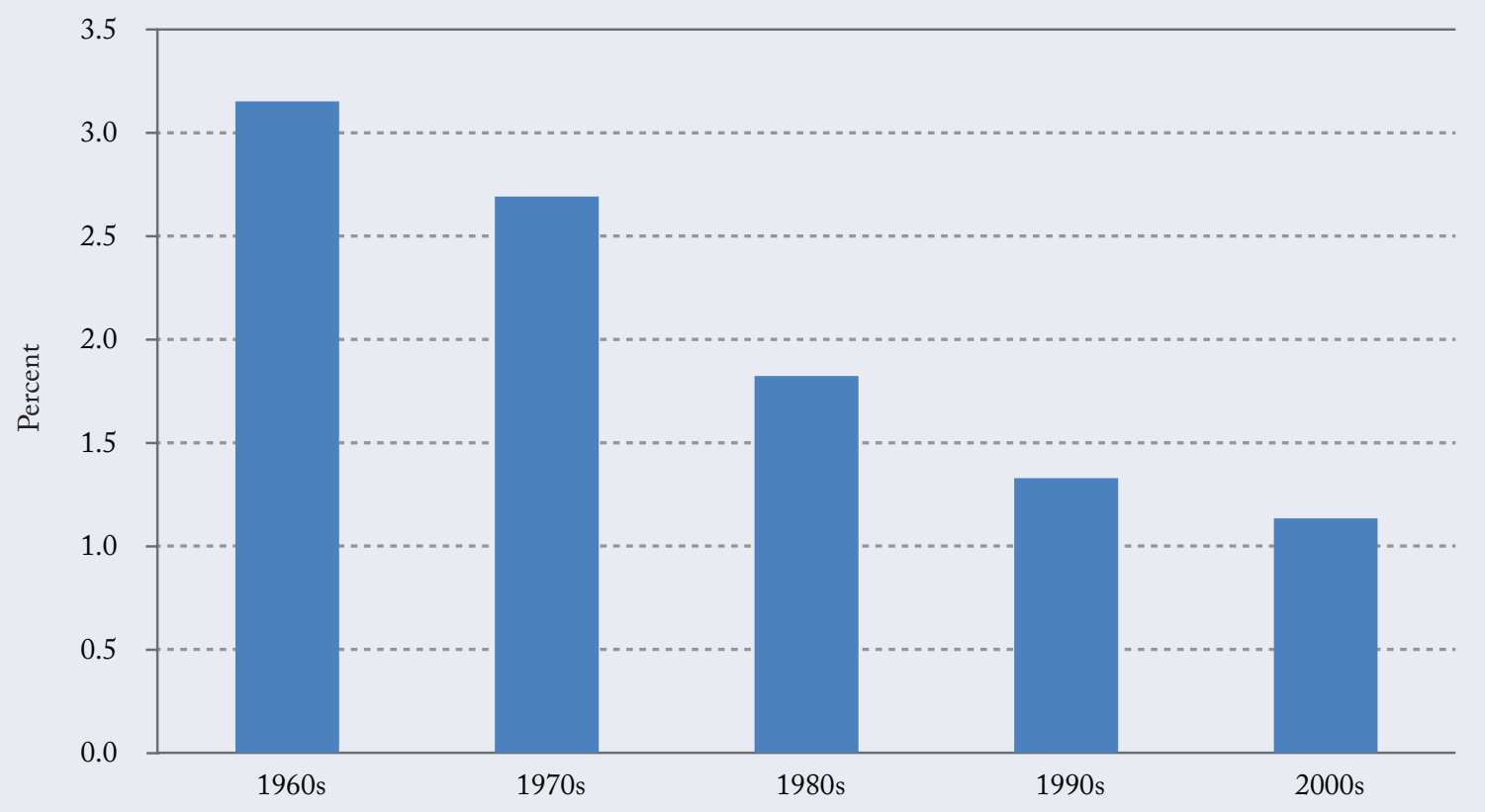

Source: Statistics Canada.

many years this view seemed plausible, but it was revealed as a fallacy when the credit bubble collapsed and the "Great Recession" took hold. Moreover, there is a counter argument to the Secular Stagnation view. The abnormally sustained low rate environment can be explained by traditional economic and financial factors. The low government bond yields could simply reflect two factors: a secular decline in the premium for longer term bonds and persistent slack in the US economy since the beginning of the Great Recession in 2008. For example, if 10-year Treasury yields are adjusted only for expected inflation, the real interest rate looks like it has been gradually decreasing since the early 1980s. But, the term premium in the 10-year Treasury yield has been decreasing, probably because inflation has not only decreased on average but also because inflation has become more predictable and inflation expectations have been well anchored. Failing to account for this produces an artificial downward trend in the calculated risk-free real interest rate. There are also additional structural forces pulling down the term premium, such as changes to banking regulation that require banks to hold more capital, which raises demand for low risk government bonds.

Figure 2, which is excerpted from Beckworth and Ponnuru (2014), shows how the 10-year bond yield can be stripped of all of its risk premiums to reach an estimate of the risk-free interest rate (the red line in the Figure) in the United States. It has dipped below 2 percent during periods of economic slowdown. The steepest drop is subsequent to the beginning of the Great Recession in 2008. If the relationship between the output gap - or the difference between the actual output of an economy and its potential output - and the risk-free real 


\section{Figure 2: Real Risk-Free Rate of Return in the US}

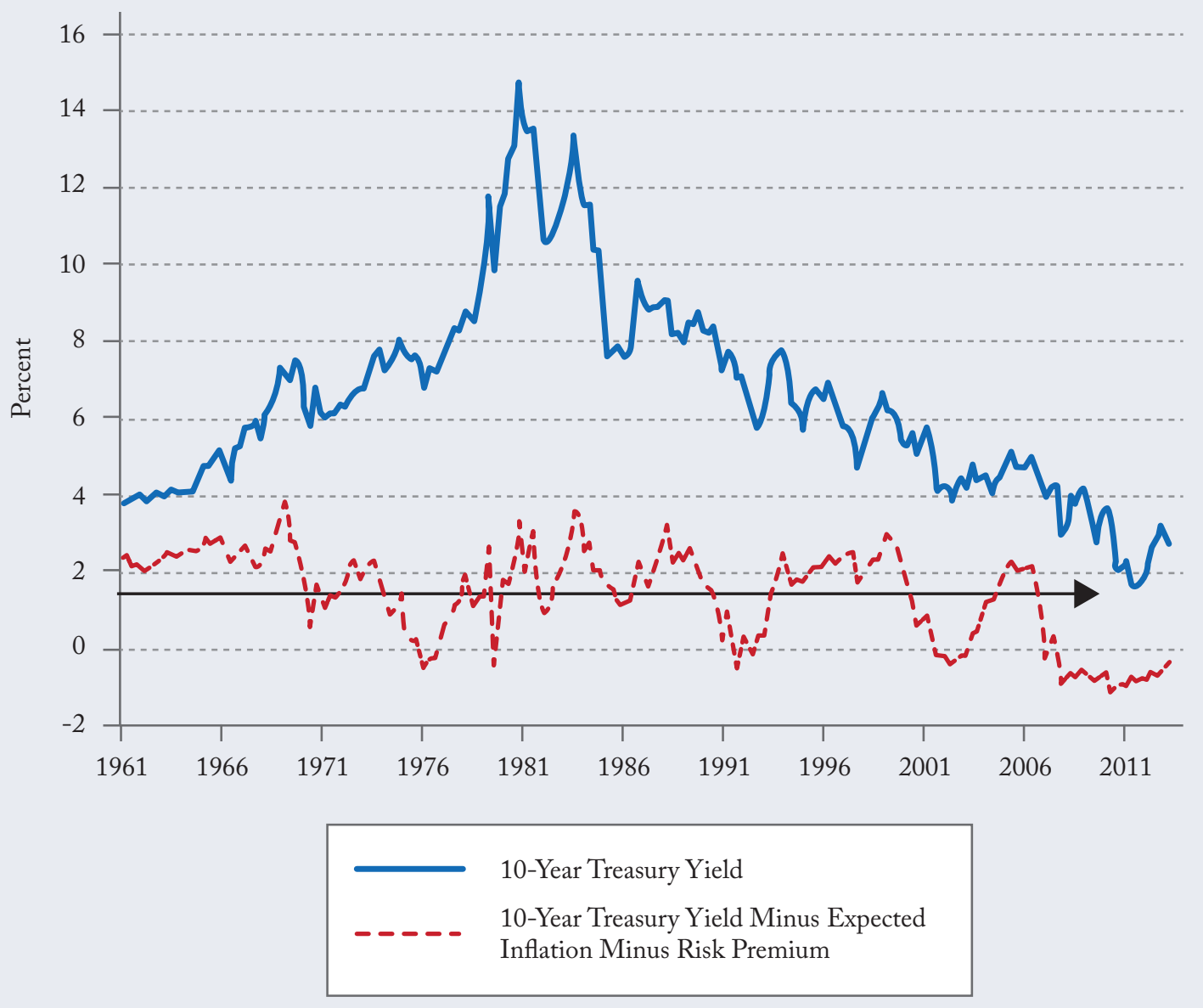

Source: Excerpted from Beckworth and Ponnuru (2014).

rate of return is stable, eliminating the output gap would give a real risk-free rate of slightly above 2 percent. While the Beckworth and Ponnuru study is about the US real risk-free rate, there have been empirical studies that demonstrate that real interest rates move very closely together across all G-7 economies, as empirically demonstrated by Desroches and Francis (2007). In other words, no secular stagnation in the US implies no secular stagnation in Canada, which can also be inferred from our strong North American trade ties.

\section{What is the Implied Risk-Free Rate in Canada?}

So, there is good reason to believe that the economic growth theory is relevant, even in today's distorted world. And, while the real risk-free rate will remain below real per capita output growth for the time being, economic theory suggests that eventually the tide will turn. When it does, a natural question is what the implied risk-free rate will be based on economic fundamentals. 
The challenge is that the outlook depends on the evolution of measurable and projectable economic quantities, like per capita economic growth and population growth, as well as on unobserved parameters, including the degree of impatience of individuals, their willingness to substitute future for current consumption, and the extent to which they value unborn household members. Bringing growth theory to bear on the longrun equilibrium level of the risk-free rate shifts the problem of extrapolating from past rates of return to one of predicting future economic and population growth and making reasonable assumptions or estimates of these unknown parameters.

Population growth is much less volatile in the short run than economic growth, and much easier to predict by extrapolating from past trends. Usefully, Statistics Canada has population projections under a variety of assumptions. Given the aging of the babyboom generation, and regardless of the immigration assumptions that one uses, it is evident that population growth in Canada has decreased and will continue to do so, as will the rate of growth of the labour force. However, the impact of labour force growth on real risk-free rates is uncertain. Estimating the weight households give to as-yet unborn members is difficult, and the role of population growth varies quite a lot depending on the particular version of the growth model that is used..$^{\mathbf{2}}$

What have investigations using the model and equation in the online Appendix estimated? Mendes (2014) concludes from empirical estimates at the Bank of Canada that the nominal "neutral rate" has fallen by a percentage point since the mid-2000s (i.e., since before the Great Recession), reflecting slower trend economic growth, slower population growth, and a reduction in the long-run level of real rates in the global economy. That work suggests that the neutral rate now stands between 3 and 4 percent - which, allowing for 2 percent inflation, puts the real risk-free level of interest rates at between 1 to 2 percent.

For these estimates to be compatible with a risk-free rate that exceeds the rate of growth of per capita output, the lower end of the Bank of Canada's 1 to 2 percent range implicitly means expecting a further slowing in the trend rate of economic growth relative to the 1.4 percent pace between 1980 and 2010 . This is quite possible when one accounts for an aging population, with lower labour force participation and the impact on hours worked.

A recent study from the Centre for the Studies of Living Standards (CSLS) by Drummond and Capeluck (2015) on long-term fiscal and economic projections provides a range of real GDP forecasts out to 2038. As cited in the publication, the CSLS and the Parliamentary Budget Office project Canadian real GDP growth to average only 1.6 percent on a trend basis. Forecasts by TD Economics anticipate a 1.7 percent pace, while the Conference Board of Canada anticipates 1.9 percent. The highest projection for 2.2 percent growth was from the Policy and Economic Analysis Program at the Rotman School of Management. If one applies the medium (M1) population growth forecast from Statistics Canada to these estimates, the implication is that annual growth in real output per capita is expected to be in a range of roughly 0.75 to 1.35 percent, shown in Figure 3. Since growth theory puts a long-term average floor on real risk-free rates, it is useful to focus on the bottom on the range, implying that the real risk-free rate could be close to, or conceivably slightly below, 1 percent.

8 The version discussed in detail here, the basic neoclassical growth model, assumes households have infinite planning horizons. Other models include "overlapping generations models" in which individuals have finite planning horizons. A tractable version of this type of model is developed by Blanchard (1985). Groth (2011) has a detailed explanation of the factors that influence long-run rates of return in this type of model. 


\section{Figure 3: Long-term Projections of Real GDP per Capita}

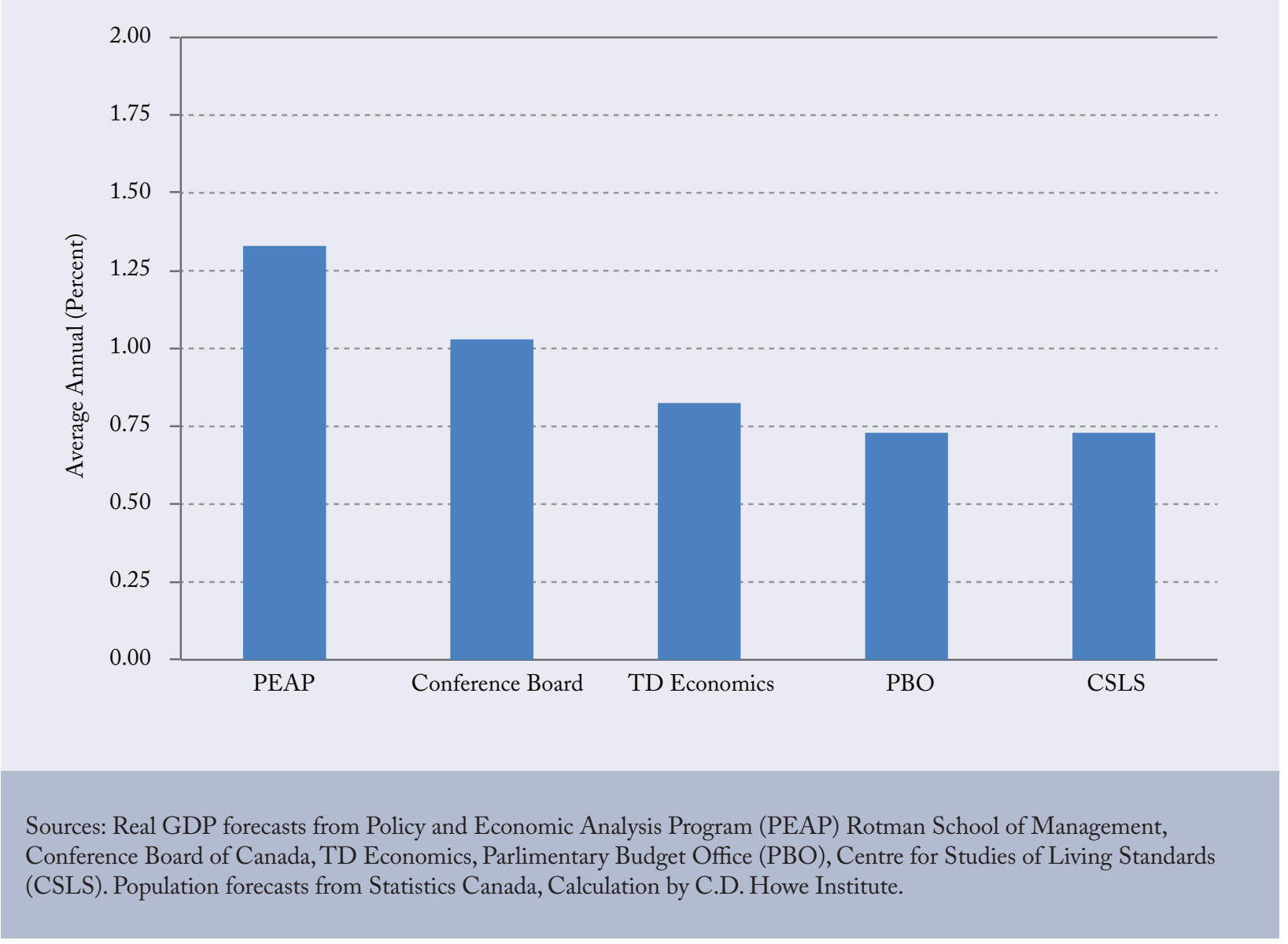

Another factor that could justify a real risk-free rate of 1 percent, or even lower in an extreme case, is that pensioners and workers close to retirement age are currently experiencing "demographic shocks" in the sense that they are coming to realize that they will probably live longer than they expected when planning for their retirement savings. As The Economist (2014) noted, "Over the past 50 years, every forecast of how long people will live has fallen short." This could lead them to increase their savings and to behave as if their degree of impatience were negative. If this effect were sufficiently strong, real rates of return could conceivably be driven below the real per capita growth rate.

Not all factors will be working to lower the real risk-free rate. For example, there is the possibility that technology and increased capital investment, incented by labour constraints caused by an aging population could boost productivity. That would raise the trend rate of growth in real output, although plausible increases in productivity growth would still leave the real risk-free rate in the 1 to 2 percent range. While this is an encouraging prospect, we would stress that from an investor's point of view, it comes with an important downside. Today's very low yields mean that the prices of financial assets are very high. An adjustment to a higher risk-free rate is likely to impose capital losses on bonds and could lower equity valuations. 


\section{Conclusion}

We have argued that modern growth theory can be used to help anchor expectations for the real risk-free interest rate in Canada, which has important implications for retirement savers, pension managers, trustees and policymakers. A standard result would predict that the real risk-free rates over the long term should be greater than the rate of real per capita growth. On this basis, the risk-free rate in Canada would be in the range of 1 to 2 percent, and the structural changes in the economy could favour the bottom of that range. Assuming the Bank of Canada maintains its 2 percent inflation target, this implies that the nominal risk-free return should return to 3 percent. At the moment, pension managers would be thrilled with such a return on highly liquid, sovereign-grade assets, and it may seem odd discussing such a high interest rate in today's economic environment.

A core issue is whether a "Secular Stagnation" holds true over future decades. If so, the risk-free rate could, indeed, be lower than economic theory suggests. However, there are many instances where perceived new world orders have been proven false. The Tech Bubble of the 1990s, the concept of the Great Moderation, the projections of the endless rise of the BRICs, are memorable experiences where it appeared for many years that the world was different this time, only for it to turn out that the laws of economics had not been repealed.

If economic theory is validated, there will be a point when the real risk-free rate once again exceeds the pace of real per capita output growth. But, the analysis also argues that when it does, the equilibrium level of riskfree rates will remain below their historical experience, which is consistent with expectations that the Canadian economy will experience only modest trend real economic growth, partly reflecting the impact of demographics. 


\section{References}

Abel, Andrew, N. Gregory Mankiw, Lawrence Summers, and Richard Zeckhauser. 1989. "Assessing Dynamic Efficiency: Theory and Evidence.” Review of Economic Studies 56: 1-20.

Attfield, Cliff, and Jonathan Temple. 2010. "Balanced Growth and the Great Ratios: New Evidence for the US and UK." Journal of Macroeconomics 32: 937-956.

Baker, Dean, Bradford DeLong, and Paul Krugman. 2002. "Asset Returns and Economic Growth.” Brookings Papers on Economic Activity 36: 289-330.

Baldwin, Richard, and Coen Teulings. 2014. Secular Stagnation: Facts, Causes and Cures. London: CEPR Press.

Barbie, Martin, Marcus Hagedorn, and Ashok Kaul. 2004. "Assessing Aggregate Tests of Efficiency for Dynamic Economies.” The B.E. Journal of Macroeconomics 4: 1-17.

Beckworth, David., and Ramesh Ponnuru. 2014. "Stagnant Economics: The Case Against 'Secular Stagnation.” National Review. October 9. Accessed at: http://people.wku.edu/david.beckworth/ secularstagnation.pdf.

Blanchard, Olivier. 1985. “Debt, Deficits and Finite Horizons.” Journal of Political Economy 93: 223-248.

Desroches, Brigitte, and Michael Francis. 2007. "World Real Interest Rates: A Global Savings and Investment Perspective." Bank of Canada Review Winter: 3-17.

Drummond, Don, and Evan Capeluck. (2015), "Long-term Fiscal and Economic Projections for Canada and the Provinces and Territories, 2014-2038," pp. 27-30. Centre for the Studies of Living Standards (CSLS).

The Economist. 2014. "My Money or Your Life.” August 23.

Groth, Christian. 2011. "Overlapping Generations Models in Continuous Time.” Lecture Notes in Advanced Macroeconomics. Mimeo, University of Copenhagen, Chapter 12.

Havranek, Tomas, Roman Horvath, Zuzana Irsova, and Marek Rusnak. 2013. "Cross-Country Heterogeneity in Intertemporal Substitution.” Working paper 11/2013, Institute of Economic Studies, Charles University, Prague. Accessed at: https://ideas.repec.org/p/fau/wpaper/wp2013_11.html.

Jones, Charles, and John Fernald. 2014. "The Future of US Economic Growth.” American Economic Review 104: 44-49

Mendes, Rhys. 2014. “The Neutral Rate of Interest in Canada." Discussion paper 2014-5, Bank of Canada.

Piketty, Thomas. 2014. Capital in the Twenty-First Century. Cambridge, MA: Harvard University Press.

Ramsey, Frank. 1928. "A Mathematical Theory of Saving." Economic Journal 38: 543-549. 
Romer, David. 2012. Advanced Macroeconomics. Fourth edition, New York: McGraw Hill.

Summers, Lawrence. 2014. "U.S. Economic Prospects: Secular Stagnation, Hysteresis, and the Zero Lower Bound." Business Economics 49: 65-73.

This E-Brief is a publication of the C.D. Howe Institute.

Steve Ambler is is the David Dodge Chair in Monetary Policy at the C.D. Howe Institute, professor in the Economics Department at the Université du Québec à Montréal, senior fellow of the Rimini Centre for Economic Analysis, and a member of the Inter-University Centre on Risk, Economic Policies and Employment (CIRPEE).

Craig Alexander is Vice President, Economic Analysis, C.D. Howe Institute.

This E-Brief is available at www.cdhowe.org.

Permission is granted to reprint this text if the content is not altered and proper attribution is provided. 